\title{
Epidemiology and treatment of psoriasis: a Brazilian perspective
}

\author{
This article was published in the following Dove Press journal: \\ Psoriasis: Targets and Therapy \\ 17 April 2015 \\ Number of times this article has been viewed
}

\author{
Gleison V Duarte' \\ Larissa Porto-Silva ${ }^{2}$ \\ Maria de Fátima Paim de \\ Oliveira' \\ 'Dermatology Department, Federal \\ University of Bahia, Salvador, ${ }^{2}$ Escola \\ Bahiana de Medicina e Saúde Pública, \\ Salvador, BA, Brazil
}

\begin{abstract}
Psoriasis is a chronic immune-mediated systemic disease that is influenced by genetic and environmental factors, is associated with comorbidities, and has a negative impact on the quality of life of affected individuals. The prevalence of psoriasis varies among different ethnic groups, but this topic has not been studied in Brazil to date. In this review, we evaluate the epidemiology and treatment of psoriasis from a Brazilian perspective. We focused on studies that involved Brazilian subjects. The prevalence of psoriasis in Brazil is estimated to be $2.5 \%$, but no population study has been performed previously. Environmental factors, such as tropical climate, in association with genetic factors, such as miscegenation, may exert a beneficial impact on the course and frequency of psoriasis in Brazil. A number of studies have advanced our understanding of the cardiovascular, ophthalmic, and oral comorbidities that are associated with psoriasis. Concerns about biological therapy, such as endemic leprosy, human T-cell lymphotropic virus (HTLV), and tuberculosis infections, are discussed. The nonavailability of treatment options for psoriasis in the public health system contradicts the Brazilian Society of Dermatology guidelines, stimulating the judicialization of access to medicines in psoriasis care.
\end{abstract}

Keywords: psoriasis, epidemiology, comorbidities, health services accessibility, health care disparities, insurance, health care costs

\section{Introduction}

Psoriasis is a chronic immune-mediated systemic disease that is influenced by genetic and environmental factors, is associated with comorbidities, and has a negative impact on the quality of life of affected individuals. ${ }^{1,2}$ This disease is characterized by welldelimited erythematous scaly plaques with variable patterns and body distributions. The most common phenotype is psoriasis vulgaris.

The worldwide prevalence of psoriasis varies from $0.6 \%$ to $4.8 \%$. ${ }^{1,3,4}$ The prevalence among different races varies from zero among Samoans and North American Indians to $11.8 \%$ among Kazakhstanis. In the USA, psoriasis is found in $0.45 \%-0.7 \%$ of African-Americans but affects $1.4 \%-4.6 \%$ of North Americans. ${ }^{5}$ Schaefer et al ${ }^{6}$ reported a psoriasis prevalence of $2.1 \%$ among 48,665 individuals in Germany. The objective of this review is to summarize Brazilian data concerning the epidemiology, comorbidities, and treatment of psoriasis.

\section{Epidemiology and comorbidities of psoriasis in Brazilian patients}

In Brazil, no previous population study has evaluated the incidence and prevalence of psoriasis. No national database or registry studies are available as in other developed 
countries; however, studies are available concerning some clinical aspects, comorbidities, and treatment regimens of psoriasis. In addition, the conclusions of national and regional surveys cannot be applied to the entire Brazilian population. Figure 1 shows Brazilian Federal Units and their respective skin color distributions and populations. In Table 1, we list the available Brazilian studies related to the epidemiology of psoriasis.

The available studies that focused on comorbidities are listed in Table 2. Silva et $\mathrm{al}^{7}$ evaluated the profile of psoriasis patients using biological drugs. The main indications for biological therapy were a poor response to other systemic treatments $(55.4 \%)$ and a psoriatic arthritis diagnosis (81.1\%). Comorbidities, primarily dyslipidemia (25.7\%), were diagnosed in $62.2 \%$ of the sample. ${ }^{7}$

Two studies that were conducted in Brazil assessed the prevalence of oral lesions in patients with psoriasis and observed that the evaluated patients exhibited no diseasespecific oral lesions. The oral lesions that were found in patients with psoriasis were also found in the control group; however, a greater prevalence of fissured tongue and geographic tongue was observed in patients with psoriasis than in the general population. ${ }^{8,9}$

Paim et $\mathrm{al}^{10}$ evaluated 50 patients with psoriasis and identified ophthalmic changes in $86 \%$ of those patients. Meibomian gland dysfunction was the most frequent ophthalmic change. Lima et $\mathrm{al}^{11}$ reported the type and frequency of ophthalmological manifestations in patients with psoriatic arthritis in Brazil. Xerophthalmia was the most common ocular finding in those patients. The authors recommended early ophthalmologic evaluation in patients with psoriatic arthritis and ophthalmologic symptoms. ${ }^{11}$

\section{Treatment of psoriasis: Brazilian consensus and protocols}

The most recently published Brazilian guideline (2012) for moderate-to-severe psoriasis (ie, psoriasis area and severity index $[\mathrm{PASI}] \geq 10$ or body service area $[\mathrm{BSA}] \geq 10$ or dermatology life quality index $[\mathrm{DLQI}] \geq 10$ ) (Figure 2) suggests an algorithm for patients without psoriatic arthritis: an initial

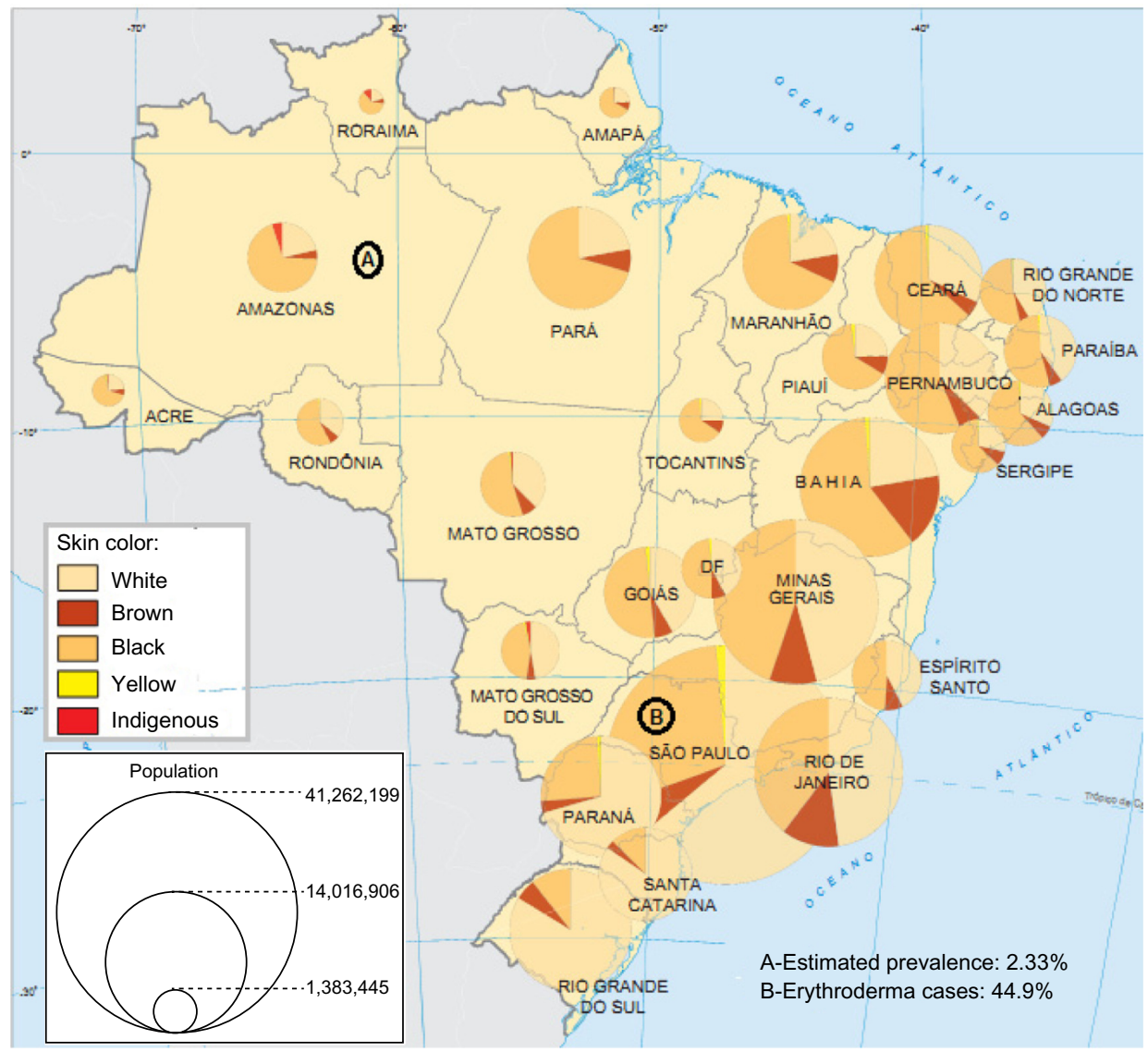

Figure I Brazilian Federal Units and their respective skin color distributions and populations.

Notes: (A) Estimated prevalence of psoriasis in an Amazonian state (Northern Brazil); ${ }^{37}$ (B) Psoriasis is the most frequent cause of erythroderma (44.9\%) in São Paulo. ${ }^{48}$ White skin color predominates in the southern states, while black and brown skin colors predominate in northeastern and northern Brazil. According to the Brazilian Society of Dermatology, the northern and southern regions were the regions with least and most expressive psoriasis-motivated consultations, respectively. Figure adapted from ibge.gov.br [homepage on the internet]. Atlas do Censo Demográfico 2010; 20I0. Available from: http://censo20I0.ibge.gov.br/apps/atlas/. ${ }^{47}$ 


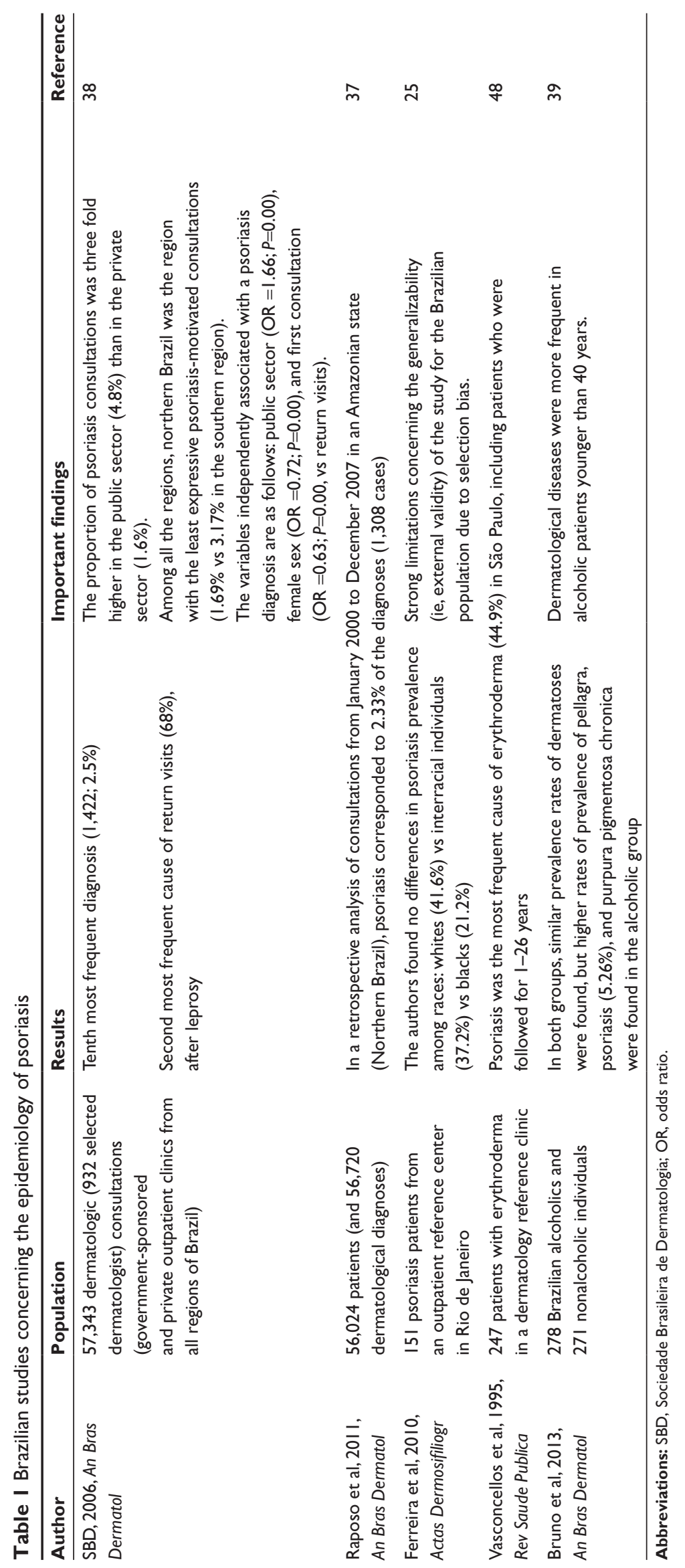




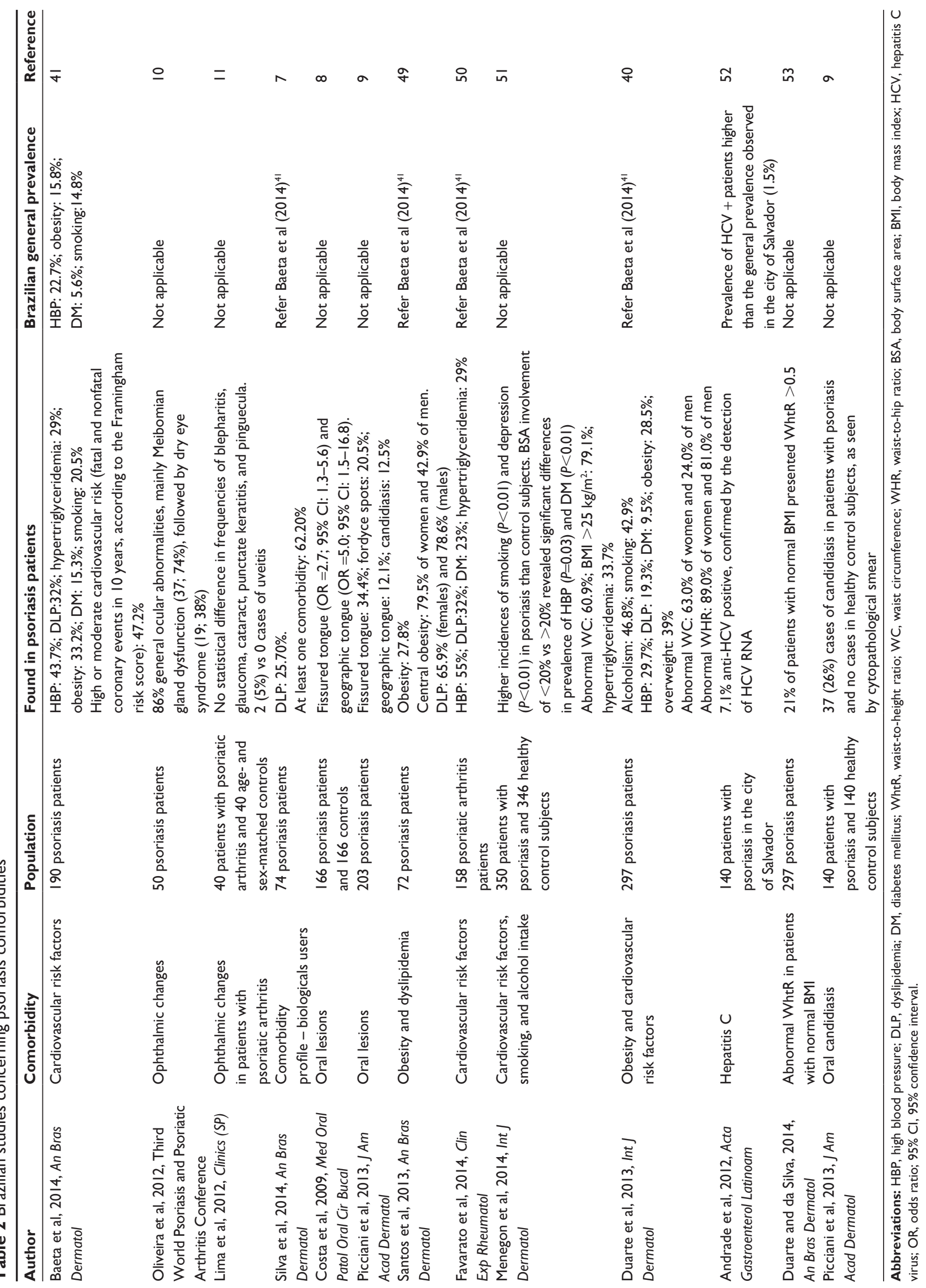




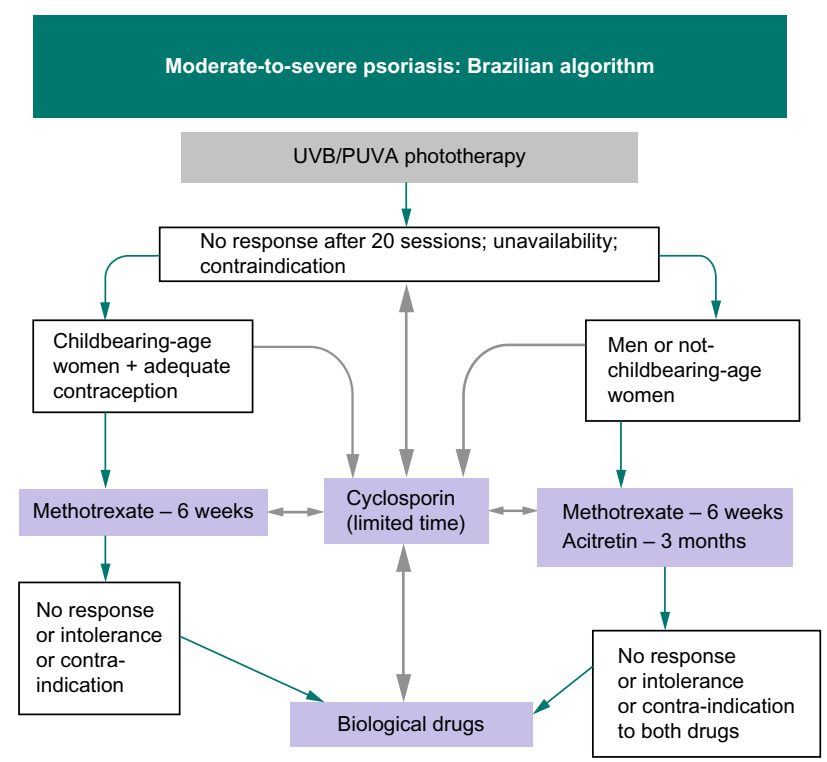

Figure 2 Algorithm of the Brazilian Society of Dermatology for moderate-to-severe psoriasis.

Notes: Copyright (C) 2012 Brazilian Society of Dermatology (SBD). Reproduced from Amaral Maia CP, Takahashi MD, Romiti R, Sociedade Brasileira De Dermatologia. Consenso Brasileiro de Psoríase 2012 - Guias de Avaliação e Tratamento. 2a ed. New York: Biblioteca; 20I2. [ISBN 978-85-89240-04-8]; ${ }^{\prime 2}$ with permission from the Brazilian Society of Dermatology (SBD).

Abbreviation: UVB/PUVA, narrow-band ultraviolet $\mathrm{B} /$ combination of psoralen and long-wave ultraviolet radiation.

phototherapy treatment, followed by classic antipsoriatic drugs (ie, acitretin/methotrexate, depending on sex and childbearing potential). ${ }^{12}$

Methotrexate should be considered when no PASI change is observed after 6 weeks of treatment or when only modest changes are observed after 10-16 weeks. Cyclosporin is suggested for a limited period of time (ie, a maximum of 2 years), for pregnant women and patients with erythrodermic psoriasis and secondary loss of response to classic or biological drugs. Biological drugs should be reserved for patients with no response or a contraindication or intolerance to at least one classic drug and phototherapy. ${ }^{12}$ Only adalimumab, infliximab, and etanercept have been approved for psoriasis and psoriatic arthritis by the health regulatory agency in Brazil (ANVISA - National Agency for Sanitary Vigilance). Ustekinumab is currently approved exclusively for psoriasis treatment. ${ }^{12}$

The biological treatment goals for moderate-to-severe psoriasis are the same as those adopted by the European consensus. ${ }^{13}$ Special issues related to Brazilian biological drug care are listed below:

1. High HTLV prevalence in many states of Brazil. ${ }^{14}$ This high prevalence raises concerns about the capacity of biological immunosuppression to induce lymphomas and HTLV-associated myelopathy in asymptomatic patients.
2. Endemic and highly prevalent tuberculosis in all regions of Brazil. Brazil has the 14th highest prevalence of tuberculosis among 22 countries and is responsible for $31 \%$ of all tuberculosis cases in Latin America. Despite compulsory Bacillus Calmette-Guérin (BCG) vaccination, there are 25-49 estimated cases of active tuberculosis per 100,000 in Brazil. ${ }^{15}$ The recent nonavailability of purified protein derivative (PPD for the Mantoux test) in nearly all regions, combined with the nonavailability of interferon- $\gamma$ release assays or other assays for public health assistance, make biological treatments much more unsafe. There is a possibility of extending latent tuberculosis treatment for all biological candidate patients in this scenario. ${ }^{16}$

3. Anti-tumor necrosis factor (TNF)- $\alpha$ drugs and ustekinumab were not included in the national clinical protocol (PCDT - the abbreviation for Clinical Protocol and Therapeutic Algorithm, in Portuguese) for psoriasis treatment. Consequently, these drugs are not reimbursed for the treatment of moderate-to-severe psoriasis. In addition, reimbursement for biological treatments for moderate-to-severe psoriasis is not mandatory for private health insurers in Brazil; only combination of psoralen (P) and long-wave ultraviolet radiation (UVA), ie, PUVA phototherapy, receives mandatory coverage for the treatment of this disease. ${ }^{17}$ This conflict in private health insurance coverage has stimulated lawsuits that aim to guarantee access to medications. From 1999 to 2009, in Minas Gerais, which is a state of southern Brazil, 2,412 lawsuits that included 2,880 medicine requests for 18 different drugs were analyzed. Among the most frequent treatments requested were adalimumab, etanercept, and infliximab. The ability to obtain medications by lawsuit may privilege people with better financial resources who are able to pay lawyers and disadvantage people with poor socioeconomic status. ${ }^{18}$ Regardless of socioeconomic status, lawsuits expose all patients to more stress. Machado et a ${ }^{19}$ confirm that only $23 \%$ of judicial representation was performed by public defenders between 2005 and 2006. Again, immunosuppressors, particularly adalimumab and etanercept, were the most requested subgroup of drugs. The authors draw attention to the aggravation of health access inequity. ${ }^{19}$

4. Low availability of phototherapy in public and private health systems. The Brazilian psoriasis consensus sent an alert to health authorities recommending the creation of new phototherapy centers because it is a highly efficacious and low-cost therapy that facilitates long-term 
Table 3 Listed reasons for the exclusion of biological treatments for psoriasis management (government protocol)

\begin{tabular}{|c|c|c|c|}
\hline $\begin{array}{l}\text { Government } \\
\text { argument }\end{array}$ & Argument critiques/questioning & Author & Reference \\
\hline \multirow[t]{3}{*}{ High cost } & $\begin{array}{l}\text { "Despite the lack of a vital threat, psoriasis is highly important to the national } \\
\text { economy and to those who have the disease" }\end{array}$ & $\begin{array}{l}\text { Radtke and Augustin, 2008, } \\
\text { Clin Dermatol }\end{array}$ & 54 \\
\hline & $\begin{array}{l}\text { Indirect costs (productivity loss, including costs of long-term sick leave } \\
\text { and disability pension) are more substantial than direct costs in Sweden }\end{array}$ & $\begin{array}{l}\text { Norlin et al, 2015, } \\
\text { Acta Derm Venereol }\end{array}$ & 55 \\
\hline & $\begin{array}{l}\text { Biological drug prescription was associated with an increase in the use } \\
\text { of anti-infective drugs and with a reduction in the use of psychoactive drugs }\end{array}$ & $\begin{array}{l}\text { Le Moigne et al, } 2014 \text {, } \\
\text { J Eur Acad Dermatol Venereol }\end{array}$ & 56 \\
\hline \multirow[t]{6}{*}{ Adverse reactions } & $\begin{array}{l}\text { Questions about the safety of other systemic drugs, especially methotrexate } \\
\text { and cyclosporin, have limited the ability of dermatologists in many countries } \\
\text { to adequately treat moderate-to-severe psoriasis }\end{array}$ & $\begin{array}{l}\text { Nast A, 2013, } \\
\text { Arch Dermatol Res }\end{array}$ & 57 \\
\hline & $\begin{array}{l}\text { Opportunistic infections were reported infrequently among } 19,04 \mid \text { patients } \\
\text { who were treated with adalimumab }\end{array}$ & $\begin{array}{l}\text { Burmester et al, 2009, } \\
\text { Ann Rheum Dis }\end{array}$ & 58 \\
\hline & $\begin{array}{l}\text { A register from the British Society of Rheumatology compared I I,798 } \\
\text { anti-TNF- } \alpha \text {-treated patients and } 3,598 \text { nonbiological DMARD-treated patients } \\
\text { and demonstrated that anti-TNF- } \alpha \text { therapy is associated with a small overall } \\
\text { risk of serious infections ( } 42 \text { vs } 32 \text { cases } / 1,000 \text { patient-years) }\end{array}$ & $\begin{array}{l}\text { Galloway et al, 20II, } \\
\text { Rheumatology (Oxford) }\end{array}$ & 59 \\
\hline & $\begin{array}{l}\text { Evidence from global clinical trials in } 3,010 \text { anti-TNF- } \alpha \text {-treated psoriasis patients } \\
\text { demonstrated that psoriasis patients had } 1.7 \text { serious infections per } \\
100 \text { patient-years, which is much lower than the frequencies observed for } \\
\text { rheumatoid arthritis and Crohn's disease (treatment of both of these conditions } \\
\text { with anti-TNF- } \alpha \text { is approved by specific protocols in Brazil) }\end{array}$ & $\begin{array}{l}\text { Burmester et al, 2013, } \\
\text { Ann Rheum Dis }\end{array}$ & 60 \\
\hline & $\begin{array}{l}\text { Tuberculosis screening resulted in a reduction of the incidence of the disease } \\
\text { by } 84 \%\end{array}$ & $\begin{array}{l}\text { Perez et al, 2005, } \\
\text { Ann Rheum Dis }\end{array}$ & 61 \\
\hline & $\begin{array}{l}\text { A meta-analysis of six controlled trials with ustekinumab revealed no statistically } \\
\text { significant differences in adverse effects between } 90 \mathrm{mg} \text { of ustekinumab, } 45 \mathrm{mg} \\
\text { of ustekinumab, and placebo }\end{array}$ & $\begin{array}{l}\text { Liu et al, 20I4, } \\
\text { Chin Med Sci J }\end{array}$ & 62 \\
\hline \multirow[t]{3}{*}{$\begin{array}{l}\text { Placebo-controlled } \\
\text { studies }\end{array}$} & $\begin{array}{l}\text { Adalimumab was compared to methotrexate and placebo in a double-blind, } \\
\text { randomized comparative 16-week study. Efficacy was assessed based on the PASI } \\
75 \text { response, which was faster ( } 8 \text { weeks) and superior in the adalimumab group. }\end{array}$ & $\begin{array}{l}\text { Saurat et al, 20II, } \\
\text { Br J Dermatol }\end{array}$ & 63 \\
\hline & $\begin{array}{l}\text { A Cochrane meta-analysis of patients from } 163 \text { randomized controlled trials } \\
(50,010) \text { found no statistically significant differences in serious adverse events } \\
\text { and serious infections between biological and nonbiological DMARDs. }\end{array}$ & $\begin{array}{l}\text { Singh et al, 20I I, } \\
\text { Cochrane Database Syst Rev }\end{array}$ & 64 \\
\hline & $\begin{array}{l}\text { For the comparisons of adalimumab vs methotrexate, infliximab vs } \\
\text { methotrexate, ustekinumab vs methotrexate, and etanercept vs } \\
\text { acitretin, there is predominantly a low strength of evidence that favors the } \\
\text { individual biological agent vs the nonbiological agent }\end{array}$ & $\begin{array}{l}\text { Lee et al, 20I2, Agency } \\
\text { for Healthcare Research } \\
\text { and Quality (US) }\end{array}$ & 65 \\
\hline Short follow-up & $\begin{array}{l}\text { Treatment with ustekinumab for up to } 5 \text { years was safe, and adverse event rates } \\
\text { were generally comparable between the ustekinumab and placebo groups }\end{array}$ & $\begin{array}{l}\text { Langley et al, 2014, } \\
\text { Br J Dermatol }\end{array}$ & 66 \\
\hline
\end{tabular}

Abbreviations: DMARD, disease-modifying antirheumatic drug; PASI, psoriasis area and severity index; TNF, tumor necrosis factor.

psoriasis control. In addition, the alert emphasized that systemic treatments, which have more adverse reactions and higher comparative costs, could be avoided or recommended to a smaller number of patients. ${ }^{12}$

5. The coexistence of leprosy and psoriasis in the same patient is rarely described in the literature. Only 20 cases of psoriasis were diagnosed among 1,450,661 individuals with leprosy. ${ }^{20,21}$ Nevertheless, cases of secondary leprosy were described after psoriasis treatment with infliximab and etanercept. It is possible that anti-TNF- $\alpha$ may interfere with the granulomatous immune response, leading to the reactivation of latent granulomatous infections and the development of opportunistic infections, such as leprosy and tuberculosis. Therefore, in our opinion, systematized investigation is recommended before starting treatment and more rigorous monitoring is recommended during anti-TNF- $\alpha$ treatment. ${ }^{20,22-24}$

A Brazilian study evaluated the frequency of PUVA and narrow-band UVB (NB-UVB) prescriptions for patients with psoriasis who have not responded to topical treatment. The prescription of NB-UVB was more frequent than that for PUVA, probably due to the smaller number of contraindications and side effects, despite the high prevalence of individuals with elevated Fitzpatrick phototypes. ${ }^{25,26}$

Studies of new therapies have been scarce in Brazil. Netto et $\mathrm{al}^{27}$ evaluated intradermal delipidated, deglycolipidated Mycobacterium vaccae (PVAC antigen) treatment in 165 
psoriasis patients who were divided into three groups (ie, $50 \mu \mathrm{g}, 15 \mu \mathrm{g}$, and placebo). The PASI 75 responses (13\%, 9\%, and $18 \%$ ) were similar among the study groups in the 12 th week $(P=0.429)$. The incidence of adverse effects was greater in the group treated with PVAC than in the placebo group (98.2\% vs $70.9 \%, P<0.001)$. These effects included primarily local non-severe reactions. Despite the safety of this method, it was not clearly superior to placebo. ${ }^{27}$

\section{Psoriasis treatment in Brazil: public and private perspectives}

Approximately 25\% of the Brazilian population (50,930 million) has contracted supplementary private health insurance, and $75 \%$ relies on treatments available from the Brazilian public health care system (Sistema Único de Saúde or SUS). ${ }^{28}$ SUS is a tax-based health care system that is based on universal access to care.

Since 2002, the Brazilian government health system has made acitretin and cyclosporin available for psoriasis treatment. ${ }^{29}$ In 2010, classic and biological anti-TNF- $\alpha$ drugs were added to the public psoriatic arthritis treatment public protocol. ${ }^{30,31}$ However, anti-TNF- $\alpha$ drugs and ustekinumab are not reimbursed for the treatment of moderate-to-severe psoriasis, as these drugs have not been included in the national clinical protocol (PCDT). ${ }^{32}$

According to data from the national program of exceptional distribution (high-cost drugs), from 2000 to 2004, the percentage of patients using acitretin was very low (1.34\% of women, $3.38 \%$ of men, and $2.08 \%$ of both sexes) compared to other high-cost drugs prescribed for other conditions. The same result was observed for cyclosporin $(2.0 \%$ of women, $4.79 \%$ of men, and $3 \%$ of both sexes), when considering the use of this drug for psoriasis and other conditions. Methotrexate was not included in this program due to its relatively low cost. Injectable methotrexate was added to the list of available drugs for psoriasis treatment only in 2013..$^{31,33}$ Despite being adopted as a psoriasis treatment option in PCDT, no study evaluating methotrexate efficacy was included due to the insufficient grade of the evidence available for this drug. ${ }^{32}$ The adoption of biologicals was considered premature by the government health system due to "high costs, adverse reactions, comparison to placebo in the majority of studies and short follow up." Curiously, the same protocol establishes severe psoriasis only when BSA $\geq 20 \%$ or PASI $\geq 12$, as suggested by Schmitt and Wozel, ${ }^{34}$ but in contrast to most guidelines.

We have raised questions about this protocol in Table 3. In spite of these questions, it remains necessary to compare costs and clinical results to support decisions in health and public policy development. A Brazilian study assessed the direct and indirect costs of psoriasis treatment. Comparing men and women, the total annual cost per patient was greater for males, who were prone to more severe psoriasis. The total cost was also related to the duration of the disease. Biological treatments had a median cost that was 22 times greater than that of systemic conventional treatments; biological treatments also had an indirect annual cost that was 55\% higher than that of systemic conventional treatments. ${ }^{35}$

Regarding access to biological treatments in Brazil, supplementary health insurance may or may not reimburse these drugs, as private payers can opt to expand coverage to those interventions, limiting access based on individual decisions or based on each health insurance company's policy. ${ }^{36}$

\section{Discussion}

The psoriasis frequencies described by the studies in Table 1 are similar to data from the literature, which estimate that $1 \%-2 \%$ of the populations in Germany, Britain, and the USA are affected. ${ }^{6,37}$ Previous data from a census provided by the Brazilian Society of Dermatology in 2005 estimated a 2.5\% frequency based on a multicentric population from 17 states, including private and public dermatology services. ${ }^{38}$ Higher frequencies were found among alcoholic individuals in comparison to nonalcoholic controls. ${ }^{39}$ Moreover, psoriasis patients also had a high prevalence (46.8\%) of alcohol consumption. ${ }^{40}$

In Brazil, it is possible that miscegenation and the tropical climate exert a beneficial impact on the psoriasis course and frequency, but it remains unclear whether mixed-race and black Brazilian individuals are less affected by psoriasis. ${ }^{25}$ As in other countries, Brazilian psoriasis patients are prone to several cardiovascular and ophthalmic comorbidities ${ }^{11,40,41}$ and emerging studies have described a considerable number of nonspecific oral manifestations. ${ }^{9}$ The frequency of hepatitis $\mathrm{C}$ infection is similar to the frequency described in Japan. ${ }^{42}$

Brazilian guideline recommendations have encountered availability problems in public and private health systems. Although phototherapy has been the first therapeutic choice for moderate-to-severe psoriasis, this treatment is rarely available in the public sector. ${ }^{12,26}$ Health insurance companies are only obligated to reimburse PUVA, which is not the first phototherapy choice of Brazilian dermatologists. ${ }^{17}$ In contrast to these guidelines, biologicals are not included in the government psoriasis treatment protocol. The problem of inadequate treatment options and insufficient access to care is addressed in the Sixty-seventh World Health Assembly, 
which recognizes psoriasis as a "chronic, noncommunicable, painful, disfiguring, and disabling disease for which there is no cure." 43 While the scientific community recognizes the importance of biological agents for the treatment of moderate-to-severe psoriasis, the financial resources necessary to fund such a high-cost treatment modality are finite and often misused, ${ }^{44}$ as noted by the low investment in the provision of phototherapy in the public health system. Difficulties regarding access have stimulated the judicialization of access to medicines in psoriasis care. ${ }^{19}$

Safety concerns related to biological treatment are an important issue, as the country has high endemic rates of leprosy, tuberculosis, and HTLV infections. ${ }^{14,15,22}$ The government protocol justifies the exclusion of biologicals for psoriasis treatment (except psoriatic arthritis) based on high costs, adverse reactions, comparison to placebo in the majority of studies, and short follow-up duration in studies. ${ }^{32}$

The fact that the Brazilian Ministry of Health protocol for psoriasis treatment does not cover biological agents makes it difficult to access these drugs. Once the need for biological therapy is verified, the individual clinical choice of which drug will be required is determined via lawsuit rather than by official documents guided by the most cost-effective medicine. ${ }^{44}$

In conclusion, our understanding of psoriasis as a multisystem disease has grown in the past decade after the publication of several psoriasis comorbidity studies in Brazil. Population studies evaluating the prevalence and distribution of this disease among races have not yet been performed. Despite the absence of psoriasis among natives of the Andean region of South America, ${ }^{45}$ Brazil has a highly miscegenated population; as a result, a dissociation between skin color and genomic ancestry ${ }^{46}$ makes it unlikely that identical results will be obtained in Amerindian Brazilians. Because Brazilian government protocol contradicts the national consensus regarding the treatment of psoriasis, studies of cost-effectiveness and additional investments in phototherapy and systemic drug availability are urgent. Otherwise, insufficient access will be aggravated by the growing number of lawsuits.

\section{Acknowledgment}

We are grateful to Otávio Nassif for reviewing the manuscript.

\section{Disclosure}

Dr Duarte and Dr Oliveira have participated as speakers for AbbVie, Janssen, and Pfizer in the past 5 years. Dr Porto-Silva reports no conflicts of interest in this work.

\section{References}

1. Lowes MA, Bowcock AM, Krueger JG. Pathogenesis and therapy of psoriasis. Nature. 2007;445(7130):866-873.

2. Friedewald VE, Cather JC, Gelfand JM, et al. AJC editor's consensus: psoriasis and coronary artery disease. Am J Cardiol. 2008;102(12): 1631-1643.

3. Gudjonsson JE, Elder JT. Psoriasis: epidemiology. Clin Dermatol. 2007;25(6):535-546.

4. Christophers E. Psoriasis-epidemiology and clinical spectrum. Clin Exp Dermatol. 2001;26(4):314-320.

5. Schön MP, Boehncke WH, Bröcker EB. Psoriasis: clinical manifestations, pathogenesis and therapeutic perspectives. Discov Med. 2005; 5(27):253-258.

6. Schaefer I, Rustenbach SJ, Zimmer L, Augustin M. Prevalence of skin diseases in a cohort of 48,665 employees in Germany. Dermatology. 2008;217(2):169-172.

7. Silva LM, Rocha Bde O, Nobre AC, Rêgo VR, Follador I, Oliveira Mde F. Anti-TNF $\alpha$ therapy in the management of psoriasis: experience of a state referral center. An Bras Dermatol. 2014;89(3):436-440.

8. Costa SC, Hirota SK, Takahashi MD, Andrade HJ, Migliari DA. Oral lesions in 166 patients with cutaneous psoriasis: a controlled study. Med Oral Patol Oral Cir Bucal. 2009;14(8):e371-e375.

9. Picciani BL, Michalski-Santos B, Carneiro S, et al. Oral candidiasis in patients with psoriasis: correlation of oral examination and cytopathological evaluation with psoriasis disease severity and treatment. $J \mathrm{Am}$ Acad Dermatol. 2013;68(6):986-991.

10. Oliveira MFP, Rocha BO, Fraga NA, et al. Ophthalmic manifestations in psoriatic patients in a Brazilian referral center. Poster presented at: 3rd World Psoriasis and Psoriatic Arthritis conference; July; 2012; Stockholm, Sweden.

11. Lima FB, Abalem MF, Ruiz DG, et al. Prevalence of eye disease in Brazilian patients with psoriatic arthritis. Clinics (São Paulo). 2012; 67(3):249-253.

12. Amaral Maia CP, Takahashi MD, Romiti R, Sociedade Brasileira De Dermatologia. Consenso Brasileiro de Psoríase 2012 - Guias de Avaliação e Tratamento. 2a ed. New York: Biblioteca; 2012. [ISBN 978-85-89240-04-8].

13. Mrowietz U, Kragballe K, Reich K, et al. Definition of treatment goals for moderate to severe psoriasis: a European consensus. Arch Dermatol Res. 2011;303(1):1-10.

14. Pinto MT, Rodrigues ES, Malta TM, et al. HTLV-1/2 seroprevalence and coinfection rate in Brazilian first-time blood donors: an 11-year follow-up. Rev Inst Med Trop Sao Paulo. 2012;54(3):123-129.

15. who.int [homepage on the internet]. Global tuberculosis control: a short update to the 2009 report; 2009. Available from: http://www.who. int/tb/publications/global_report/2009/update/en/) website. Accessed November 25, 2014.

16. Suvisa.ba.gov.br [homepage on the internet]. Recomendações para controle de contatos e tratamento da infecção latente da tuberculose na indisponibilidade transitória do Derivado Proteico Purificado; 2014. Available from: http://www.suvisa.ba.gov.br/sites/ default/files/vigilancia_epidemiologica/doencas_transmissiveis/ arquivo/2014/10/15/Nota $\% 20$ Informativa $\% 2008 \% 20 \mathrm{de} \% 20$ set $\% 20$ 2014\%20-\%20Recomenda\%C3\%A7\%C3\%b5es\%20Controle $\% 20$ Contatos.pdf. Accessed November 25, 2014.

17. ans.gov.br [homepage on the internet]. Resolução Normativa - RN N ${ }^{\circ}$ 262, de 1 de agosto de 2011. Rol de Procedimentos; 2012: Fototerapia com PUVA. Available from: http://www.ans.gov.br/images/stories/ noticias/pdf/rn\%20262.pdf. Accessed November 25, 2014.

18. Campos Neto OH, Acurcio Fde A, Machado MA, et al. Doctors, lawyers and pharmaceutical industry on health lawsuits in Minas Gerais, Southeastern Brazil. Rev Saude Publica. 2012;46(5):784-790.

19. Machado MA, Acurcio Fde A, Brandão CM, et al. Judicialization of access to medicines in Minas Gerais state, Southeastern Brazil. Rev Saúde Pública. 2011;45(3):590-598.

20. Dogra S, Kaur I, Kumar B. Leprosy and psoriasis: an enigmatic relationship. Int J Lepr Other Mycobact Dis. 2003;71(4):341-344. 
21. Kumar B, Raychaudhuri SP, Vossough S, Farber EM. The rare coexistence of leprosy and psoriasis. Int J Dermatol. 1992;31(8): $551-554$.

22. Teixeira FM, Vasconcelos LM, Rola Cde A, Almeida TLP, Valença JT Jr, Nagao-Dias AT. Secondary leprosy infection in a patient with psoriasis during treatment with infliximab. J Clin Rheumatol. 2011;17(5): 269-271.

23. Lydakis C, Ioannidou D, Koumpa I, et al. Development of lepromatous leprosy following etanercept treatment for arthritis. Clin Rheumatol. 2012;31(2):395-398.

24. Antonio JR, Soubhia RM, Paschoal Vdel A, Amarante CF, Travolo AR. Biological agents: investigation into leprosy and other infectious diseases before indication. An Bras Dermatol. 2013;88(6 Suppl 1): $23-25$.

25. Ferreira CP, Martins CJ, Issa PR, Oliveira RVC, Da-Cruz AM. Psoriasis affects individuals of African descent and white Brazilians similarly. Actas Dermosifiliogr. 2010;101(3):230-234.

26. Duarte I, Cunha JA, Bedrikow RB, Lazzarini R. What is the most common phototherapy prescription for psoriasis: NB-UVB or PUVA? Prescription behavior. An Bras Dermatol. 2009;84(3):244-248.

27. Netto EM, Takahashi D, de Fátima Paim de Oliveira M, et al. Phase II randomized, placebo-controlled trial of $\mathrm{M}$. Vaccae-derived protein (PVAC) for the treatment of psoriasis. Vaccine. 2006;24(23): 5056-5063.

28. ans.gov.br [homepage on the internet]. Dados e indicadores do setor; 2014. Available from: http://www.ans.gov.br/perfil-do-setor/dados-eindicadores-do-setor. Accessed November 25, 2014.

29. BRASIL. Ministério da Saúde. Portaria n. ${ }^{\circ} 1.318$ de 23 de julho de 2002. Define, para o grupo 36, medicamentos, da tabela descritiva do sistema de informações ambulatoriais do Sistema Único de Saúde - SIA/ SUS, a forma e a redação estabelecidas no anexo desta portaria. Seção 1. Diário Oficial da República Federativa do Brasil, Poder Executivo, Brasília, DF; 24 jul 2002.

30. BRASIL. Ministério da Saúde. Portaria $n^{\circ} 2.981$ de 26 de novembro de 2009. Aprova o Componente Especializado da Assistência Farmacêutica. Seção 1, p. 31. Diário Oficial da República Federativa do Brasil, Poder Executivo, Brasília, DF, de 01 dez; 2009.

31. Acurcio FA, Brandão CMR, War AA Jr, et al. Perfil demográfico e epidemiológico dos usuários de medicamentos de alto custo no Sistema Único de Saúde [Epidemiological profile of high cost medicines users in the Brazilian Health System]. Rev Bras Estud Popul. 2009;26(2): 263-282.

32. portal.saude.gov [homepage on the internet]. Clinical protocol for the treatment of moderate to severe psoriasis. PCDT; 2004. Available from: http://portal.saude.gov.br/portal/saude/profissional/visualizar_texto. cfm?Idtxt=28510. Accessed November, 25, 2014.

33. bvsms.saude.gov.br [homepage on the internet]. Portaria no 44, de 9 de setembro de 2013. Torna pública a decisão de incorporar o medicamento metotrexato injetável para o tratamento da psoríase no Sistema Único de Saúde - SUS; 2013. Available from: http://bvsms.saude.gov. br/bvs/saudelegis/sctie/2013/prt0044_09_09_2013.html. Accessed November 25, 2014.

34. Schmitt J, Wozel G. The psoriasis area and severity index is the adequate criterion to define severity in chronic plaque-type psoriasis. Dermatology. 2005;210:194-199.

35. Garcia MM. Custo da doença e perfil dos pacientes com psoríase moderada a grave atendidos no Hospital de Clínicas da Universidade Federal do Paraná. [Cost of Illness and Profile of Patients with Moderate to Severe Psoriasis Treated at the Hospital das Clinicas of the Federal University of Paraná] [dissertation]. Curitiba: Universidade Federal do Paraná; 2013.

36. Morais A, Ribeiro R, Lima R, Suehiro R. Impacto orçamentário do tratamento biológico da psoríase moderada a grave no SUS: uma ferramenta para tomadores de decisão [Budget impact analysis of biologic treatments of moderate to severe psoriasis in the Brazilian Public Healthcare System: a tool for decision-makers]. J Bras Econ Saúde. 2010;3(1):174-180.
37. Raposo AA, Schettini APM, Sardinha JCG, Pedrosa VL. Nosological profile in a dermatology referral center in the state of Amazonas - Brazil. An Bras Dermatol. 2011;86(3):463-468.

38. Sociedade Brasileira de Dermatologia. Perfil nosológico das consultas dermatológicas no Brasil. [Nosologic profile of dermatologic visits in Brazil]. An Bras Dermatol. 2006;81(6):549-558.

39. Bruno MC, Vilela MA, Oliveira CA. Study on dermatoses and their prevalence in groups of confirmed alcoholic individuals in comparison to a non-alcoholic group of individuals. An Bras Dermatol. 2013;88(3): 368-375.

40. Duarte GV, Oliveira Mde F, Cardoso TM, et al. Association between obesity measured by different parameters and severity of psoriasis. Int J Dermatol. 2013;52(2):177-181.

41. Baeta IGR, Bittencourt FV, Gontijo B, Goulart EMA. Comorbidities and cardiovascular risk factors in patients with psoriasis. An Bras Dermatol. 2014;89(5):735-744.

42. Imafuku S, Naito R, Nakayama J. Possible association of hepatitis C virus infection with late-onset psoriasis: a hospital-based observational study. J Dermatol. 2013;40(10):813-818.

43. World Health Organization. Psoriasis. In: Proceedings of the sixtyseventh world health assembly; May 24, 2014; Geneva, Switzerland. Available from: http://apps.who.int/gb/ebwha/pdf_files/WHA67/ A67_R9-en.pdf. Accessed November 25, 2014.

44. Riveros, BS. Agentes biológicos no tratamento da psoríase moderada a grave: uma avaliação farmacoeconômica [Biological Agents in the Treatment of Moderate to Severe Psoriasis: A Pharmacoeconomic Evaluation] [dissertation]. Curitiba: Universidade Federal do Paraná; 2014.

45. Chandran V, Raychaudhuri SP. Geoepidemiology and environmental factors of psoriasis and psoriatic arthritis. J Autoimmun. 2010;34(3): J314-J321.

46. Magalhães da Silva T, Sandhya Rani MR, de Oliveira Costa GN, et al The correlation between ancestry and color in two cities of Northeast Brazil with contrasting ethnic compositions. Eur J Hum Genet. 2014.

47. ibge.gov.br [homepage on the internet]. Atlas do Censo Demográfico 2010; 2010. Available from: http://censo2010.ibge.gov.br/apps/atlas/. Accessed November 25, 2014.

48. Vasconcellos C, Domingues PP, Aoki V, Miyake RK, Sauaia N, Martins JE. Erythroderma: analysis of 247 cases. Rev Saude Publica. 1995;29(3): $177-182$.

49. Santos M, Fonseca HM, Jalkh AP, Gomes GP, Cavalcante AS. Obesity and dyslipidemia in patients with psoriasis treated at a dermatologic clinic in Manaus. An Bras Dermatol. 2013;88(6):913-916.

50. Favarato MH, Mease P, Gonçalves CR, Gonçalves SC, SampaioBarros PD, Goldenstein-Schainberg C. Hypertension and diabetes significantly enhance the risk of cardiovascular disease in patients with psoriatic arthritis. Clin Exp Rheumatol. 2014;32(2):182-187.

51. Menegon DB, Pereira AG, Camerin AC, Cestari T. Psoriasis and comorbidities in a southern Brazilian population: a case-control study. Int J Dermatol. 2014;53(11):518-525.

52. Andrade DL, de Oliveira Mde F, de Souza TF, et al. A study about hepatitis $\mathrm{C}$ virus infection in patients with psoriasis in a Brazilian reference center. Acta Gastroenterol Latinoam. 2012;42(4):285-290.

53. Duarte GV, da Silva LP. Correlation between psoriasis' severity and waist-to-height ratio. An Bras Dermatol. 2014;89(5):846-847.

54. Radtke MA, Augustin M. Economic considerations in psoriasis management. Clin Dermatol. 2008;26(5):424-431.

55. Norlin JM, Steen Carlsson K, Persson U, Schmitt-Egenolf M. Resource use in patients with psoriasis after the introduction of biologics in Sweden. Acta Derm Venereol. 2015;95(2):156-161.

56. Le Moigne M, Sommet A, Lapeyre-Mestre M, et al. Healthcare cost impact of biological drugs compared with traditional systemic treatments in psoriasis: a cohort analysis in the French insurance database. J Eur Acad Dermatol Venereol. 2014;28(9):1235-1244.

57. Nast A, Mrowietz U, Kragballe K, et al. Barriers to the prescription of systemic therapies for moderate-to-severe psoriasis - a multinational cross-sectional study. Arch Dermatol Res. 2013;305(10):899-907. 
58. Burmester GR, Mease P, Dijkmans BA, et al. Adalimumab safety and mortality rates from global clinical trials of six immune-mediated inflammatory diseases. Ann Rheum Dis. 2009;68(12):1863-1869.

59. Galloway JB, Hyrich KL, Mercer LK, et al; BSRBR Control Centre Consortium, British Society for Rheumatology Biologics Register. Anti-TNF therapy is associated with an increased risk of serious infections in patients with rheumatoid arthritis especially in the first 6 months of treatment: updated results from the British Society for Rheumatology Biologics Register with special emphasis on risks in the elderly. Rheumatology (Oxford). 2011;50(1):124-131.

60. Burmester GR, Panaccione R, Gordon KB, Mcllraith MJ, Lacerda AP. Adalimumab: long-term safety in 23458 patients from global clinical trials in rheumatoid arthritis, juvenile idiopathic arthritis, ankylosing spondylitis, psoriatic arthritis, psoriasis and Crohn's disease. Ann Rheum Dis. 2013;72(4):517-524.

61. Perez J, Kupper H, Spencer-Green G. Impact of screening for latent TB before initiating anti-TNF therapy in North America and Europe [abstract]. Ann Rheum Dis. 2005;3(64 Suppl):265.
62. Liu Y, Gong JP, Li WF. Therapeutic effect and safety of ustekinumab for plaque psoriasis: a meta-analysis. Chin Med Sci J. 2014;29(3): 131-138.

63. Saurat JH, Langley RG, Reich K, Unnebrink K, Sasso EH, Kampman W. Relationship between methotrexate dosing and clinical response in patients with moderate to severe psoriasis: subanalysis of the CHAMPION study. Br J Dermatol. 2011;165(2):399-406.

64. Singh JA, Wells GA, Christensen R, et al. Adverse effects of biologics: a network meta-analysis and cochrane overview. Cochrane Database Syst Rev. 2011;16(2):CD008794.

65. Lee S, Coleman CI, Limone B, et al. Biologic and Nonbiologic Systemic Agents and Phototherapy for Treatment of Chronic Plaque Psoriasis. Rockville, MD: Agency for Healthcare Research and Quality (US); 2012.

66. Langley RG, Lebwohl M, Krueger GG, et al; The PHOENIX 2 Investigators. Long-term efficacy and safety of ustekinumab, with and without dosing adjustment, in patients with moderate-to-severe psoriasis: results from the PHOENIX 2 study through 5 years of follow-up. Br J Dermatol. Epub 2014.
Psoriasis: Targets and Therapy

\section{Publish your work in this journal}

Psoriasis: Targets and Therapy is international, peer-reviewed, open access journal focusing on psoriasis, nail psoriasis, psoriatic arthritis and related conditions, identification of therapeutic targets and the optimal use of integrated treatment interventions to achieve improved outcomes and quality of life. The manuscript management system
Dovepress

is completely online and includes a very quick and fair peer-review system. Visit http://www.dovepress.com/testimonials.php to read real quotes from published authors. 